\title{
Article/Artigo
}

\section{Injuries and envenoming by aquatic animals in fishermen of Coxim and Corumbá municipalities, State of Mato Grosso do Sul,Brazil: identification of the causative agents, clinical aspects and first aid measures}

\author{
Traumas e envenenamentos por animais aquáticos em pescadores de Coxim e Corumbá, \\ Estado de Mato Grosso do Sul, Brasil: identificação de agentes causadores, aspectos clínicos \\ e medidas de primeiros socorros
}

\author{
Geovane Cândido da Silva ${ }^{1}$, José Sabino ${ }^{1}$, Cleber José Rodrigues Alho ${ }^{1}$, Vânia Lúcia Brandão Nunes ${ }^{1}$ and \\ Vidal Haddad Junior ${ }^{2}$
}

\begin{abstract}
Introduction: The fishes of continental Brazil have socioeconomic importance due to their potential for sport fishing and commercial and subsistence uses, as seen in the Upper Paraguay River Basin, particularly in the municipalities of the Pantanal region, where it is the second largest economic activity. Injuries caused in professional fishermen are common and poorly studied, as in other regions of the country. Methods: Data were obtained from questionnaires and interviews with 100 professional fishermen, 50 in each municipality, between December 2008 and October 2009. Results: All the fishermen reported some kind of injury caused by fish stings (78\% of injuries) and fish, alligator and snake bites (22\%) on the hands ( $46 \%$ of cases) and feet (35\% of cases). Most of the patients had mild symptoms. The most severe cases were associated with secondary bacterial infections and required specific treatment and prolonged recovery associated with social and economic losses. Conclusions: The results of this study indicate that the stressful work conditions, inattention to basic preventive measures and carelessness were factors that contributed to accidents and that the toxicity and ability to inflict mechanical trauma of some aquatic species, plus the ineffective use of first aid and hospital treatment, contributed to the high morbidity and complications in many cases. Data from this study are relevant to the fishing communities of the Pantanal region, since they reveal high rates of accidents, lack of knowledge concerning first aid, initial treatment, injury prevention and lack of medical follow-up of the population.
\end{abstract}

Key-words: Fish. Venomous animals. Trauma. Fishermen. Public health. Pantanal.

\section{RESUMO}

Introdução: Os peixes continentais do Brasil têm grande importância socioeconômica, tanto pelo potencial para a pesca esportiva, quanto para a pesca comerciale de subsistência, comoénotado na bacia do Alto Rio Paraguai, particularmente, nos municípios da região do Pantanal. Ferimentose envenenamentos em pescadores profissionais são comuns e pouco estudados. Métodos: Foram entrevistados 100 pescadores profissionais, 50 em cada município, entre dezembro/2008 e outubro/2009. Resultados: Todos relataram ter sofrido algum tipo de acidente, sendo estes causados por ferrões de peixes ( $78 \%$ dos acidentados) e mordidas de peixes, jacarés ou serpentes (22\%), estes ocorridos em maioria nas mãos (46\% dos casos) epés ( $35 \%$ dos casos). A maioria dos pacientes apresentou sintomasleves. Os casos mais graves apresentavaminfecções bacterianas enecessitaram de tratamento específicoetempoprolongado de recuperação, o que condicionou às vítimas prejuízos socioeconômicos. Conclusões: Os resultados deste estudo indicam que, no plano social, as condições estressantes do trabalho, a desatenção com medidas preventivas básicas e o descuido foram os fatores que mais contribuíram para os acidentes. Por outrolado, a capacidade de algumas espécies de envenenar ou de produzir traumasmecânicose o emprego de primeiros socorros e tratamentos hospitalares ineficazes contribuíram para a grande morbidade e complicações em muitos casos. Os dados deste estudo são relevantes para as comunidades pesqueiras do Pantanal, uma vez que revelam altos índices de acidentes de trabalho, inexistência de noções de primeiros socorros ou prevenção dos acidentes e ausência de atendimento médico continuado junto a estas populações.

Palavras-chaves: Peixes. Animais peçonhentos. Traumas. Pescadores. Saúde pública. Pantanal.

1. Department of Zoology, Universidade Anhanguera, Campo Grande, MS, Brazil. 2. Department of Dermatology, Faculdade de Medicina de Botucatu, Universidade Estadual Paulista, Botucatu, SP, Brazil. Address to: Dr. Geovane Cândido da Silva. UNIDERP. Rua Alexandre Herculano 1400, Jardim Veraneio, 79037-280 Campo Grande, MS, Brasil.

Phone 5514 3882-4922

e-mail: gcsilvaet@yahoo.com.br

Received in 13/05/2010

Accepted in 21/07/2010

\section{INTRODUCTION}

The fishes of continental Brazil have socioeconomic importance for several Brazilian states, due to the potential of sport fishing and commercial and subsistence activities, as seen in the Upper Paraguay River Basin, particularly in the municipalities of the Pantanal region, where it is the second most important economic activity ${ }^{1}$. In the Pantanal region, the towns Coxim and Corumbá, in the State of Mato Grosso do Sul, and the towns of Poconé and Cáceres, in the State of Mato Grosso, are the main representatives of the economic region for their importance in the production and marketing of cattle and activities like tourism, which is fueled by the sport of amateur and professional fishing ${ }^{2}$.

Injuries to humans caused by aquatic animals, whether marine or freshwater, are common and can be observed in many situations, causing painful processes, necrosis, mutilation, high morbidity and even mortality. These accidents are caused by teeth capable of tearing, as in piranha bites, or by perforating teeth, such as venomous snakes, when they act as instruments of inoculation, and stings, bony structures common in the fish of the order Siluriformes (catfish and sorubins, among others). Most injuries occur in fishermen, who may require long recovery periods, remaining days without being able to work, causing them social and economic dificulties ${ }^{3}$.

Regarding the Pantanal region, despite the high potential for tourism and capturing noble fish, like the pacu (Piaractus mesopotamicus), sorubins (Pseudoplatystoma spp), dourado (Salminus brasiliensis), jau (Zungaro jahu), piavuçu (Leporinus macrocephalus), piraputanga (Brycon hilarii), barbado (Pinirampus pinirampu), jurupoca (Hemisorubim platyrhinchos), jurupencem (Sorubim lima) and others, there are no reports studying traumatic injuries caused by animals among the fishermen of the region ${ }^{4}$. Many of these noble species and other 
species, such as the piranhas (Serrasalminae subfamily), traíras (Hoplias malabaricus), freshwater stingrays (Potamotrygon sp), small catfish (Pimelodus sp, Pimelodella sp and Rhamdia sp), thorny catfish (Doradidae family), armored catfish (Loricadae family) and others, are capable of cause serious accidents due to stings or bites.

\section{METHODS}

A retrospective study was conducted in two stages: first in the town of Coxim during the months of October 2008 and February 2009 and the second in Corumbá, in October and November 2009. One hundred fishermen were interviewed ( 50 in each town). They were chosen randomly, following an active search made by the authors, from among the 1,750 fishermen who regularly work in the rivers that form the flood plains in Corumbá region (Paraguay River) and Coxim (Taquari River) (Figure 1) in the Z1 colony (Corumbá) and Z2 colony, in Coxim. Traveling fieldworks were held sporadically in local concentrations of fishermen in order to obtain prior contact and consent for the interviewers. The interviewers tried to get a at least six respondents in each of the different districts and villages of the fishermen, ending the visits after 50 individuals had been interviewed in each municipality.

In Coxim, contacts and interviews were facilitated because the fishermen conducted fishing trips to the Pantanal and at the time of the study, many were closed for business due to the prohibition on fishing during the fish breeding season. Fishermen of the colony affiliated with the local Z1-Corumbá were interviewed in Corumbá General Harbor and Ladário Harbor.
The interview characterized the most recent injury suffered by the fishermen, without worrying about the time elapsed from the time of injury until the time of the interview. The interviews were combined with the application of a questionnaire regarding aspects of the injuries, which contained questions about the individual's age, the date and time of the accident, number of accidents, the circumstances of the accident, the body site affected, the animal that caused it, the type of skin lesions, duration and intensity of pain, accompanying symptoms and treatments. Additional information was also collected, such as the layoff period from work due to injury, seeking medical services, until medical treatment was received, specific treatments and sequelae.

\section{Ethical considerations}

The fishermen were asked to read and sign a consent form for their participation in every interview, in accordance with the Ethical Committee of UNIDERP. From the questionnaires and responses provided, data were obtained regarding the occurrence of accidents, the identification of aquatic animals involved in trauma, clinical aspects of injuries and first aid measures.

\section{RESULTS}

The main data are shownin Tables 1 and 3, for ease ofinterpretation. All the fishermen interviewed reported having had some kind of injury caused by any aquatic animal (Table 1). The conditions that favored traumas and envenoming were ordinary actions related to the exercise of their activities.

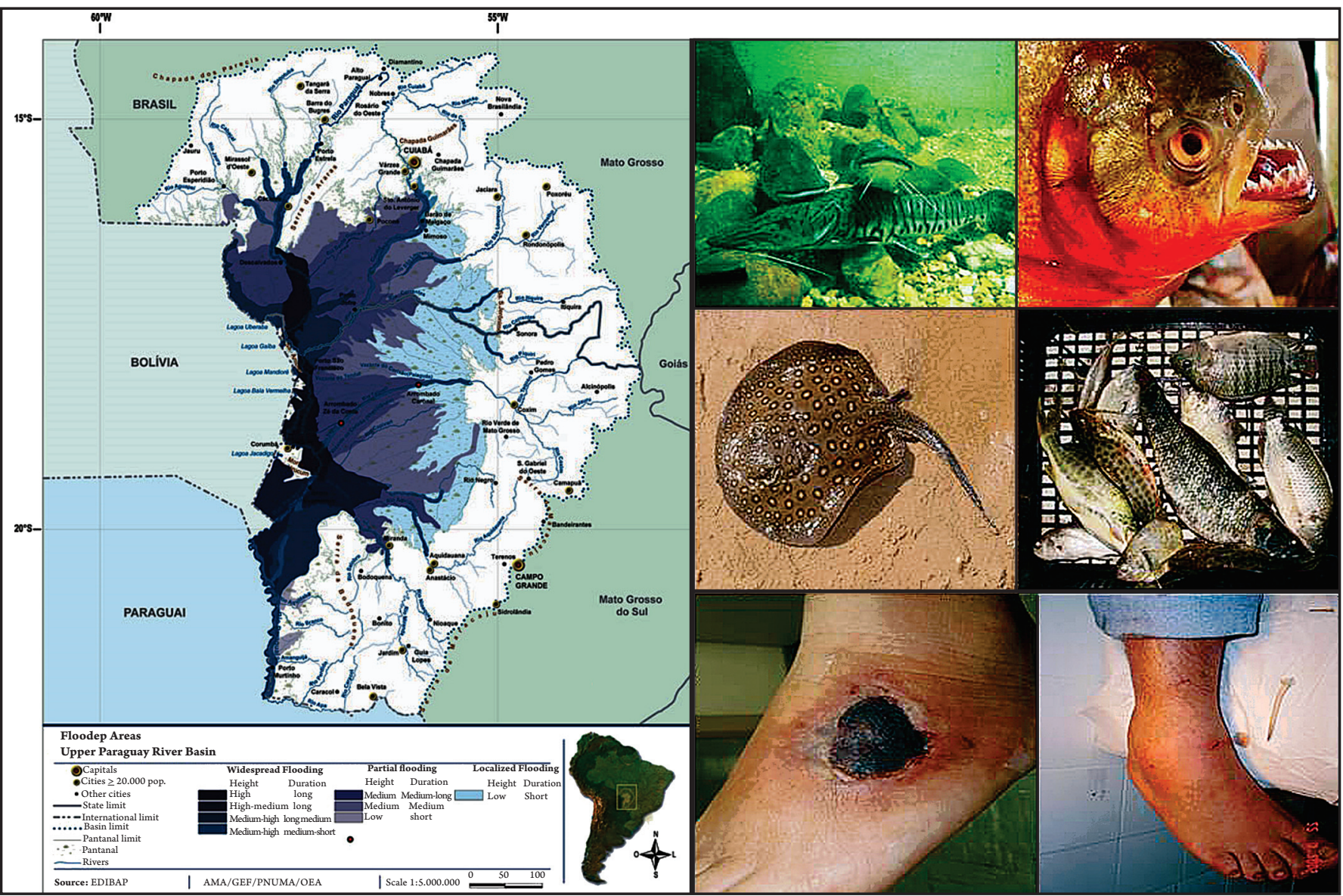

FIGURE 1 - Left: Flooded areas of the Upper Paraguay River Basin in the States of Mato Grosso and Mato Grosso do Sul, indicating the municipalities of Coxim and Corumbá (Source: ANA, GEF, UNEP, OAS, 2004). Right (up): sorubim (left), piranha, freshwater stingray and mandi. Below: skin necrosis caused by envenoming by a freshwater stingray (with necrosis) and an earlier injury caused by the sting of a sorubim (see the sting near the wound). 


\begin{tabular}{|c|c|c|c|}
\hline Town & Coxim & Corumbá & Occurrence \\
\hline Variable & $\mathrm{n}$ & $\mathrm{n}$ & $\%$ \\
\hline \multicolumn{4}{|l|}{ Period of the day } \\
\hline morning & 16 & 27 & 43.0 \\
\hline afternoon & 20 & 15 & 35.0 \\
\hline night & 14 & 13 & 27.0 \\
\hline \multicolumn{4}{|l|}{ Body place } \\
\hline hand & 23 & 23 & 46.0 \\
\hline foot & 20 & 15 & 35.0 \\
\hline arm & 1 & 2 & 3.0 \\
\hline leg & 6 & 8 & 14.0 \\
\hline thorax & - & 2 & 2.0 \\
\hline \multicolumn{4}{|l|}{ Activity } \\
\hline removing the fish from the hooks or net & 22 & 19 & 41.0 \\
\hline walking in the water & 7 & 9 & 16.0 \\
\hline walking in the boat or on the margin (step on, touch) & 5 & 12 & 17.0 \\
\hline handling the fish & 16 & 10 & 26.0 \\
\hline
\end{tabular}

\begin{tabular}{|c|c|c|c|}
\hline Town & Coxim & Corumbá & Occurrence \\
\hline Variable & $\mathbf{n}$ & $\mathbf{n}$ & $\%$ \\
\hline \multicolumn{4}{|l|}{ Causer animal } \\
\hline catfish (Pimelodus sp, Pimelodella sp and Rhamdia sp) & 10 & 13 & 23.0 \\
\hline stingrays (Potamotrygon motoro, P. falkneri, P. brachyura) & 7 & 9 & 16.0 \\
\hline dourado (Salminus brasiliensis) & 1 & 0 & 1.0 \\
\hline piranhas (Pygocentrus nattereri, Serrasalmus marginatus) & 4 & 12 & 16.0 \\
\hline sorubins (Pseudoplatystoma sp) & 14 & 10 & 24.0 \\
\hline jurupencem (Sorubim lima) & 9 & 3 & 12.0 \\
\hline jurupoca (Hemisorubim platyrhynchos) & 3 & 0 & 3.0 \\
\hline traíra (Hoplias malabaricus) & 1 & 0 & 1.0 \\
\hline caiman (Caiman yacare) & 1 & 1 & 2.0 \\
\hline snake (Bothrops sp) & 0 & 2 & 2.0 \\
\hline \multicolumn{4}{|l|}{ Cause } \\
\hline bites & 7 & 15 & 22.0 \\
\hline stings & 43 & 35 & 78.0 \\
\hline
\end{tabular}

Analysis of the data also clarified that inattention to the proper use of primary safety equipment, such as working barefoot, recklessness when it came to handling live fish when removing them from the hook or net fishing and displacement inside the boat, all facilitated the causes of accidents, which mainly affected the hands (46\%) and legs (35\% of cases) of fishermen.

Bites were responsible for $22 \%$ of cases (Table 2) and were mainly caused by piranhas (Pygocentrus nattereri and Serrasalmus marginatus), dourados (Salminus brasiliensis) and caiman (Caiman yacare).

Injuries caused by stings were responsible for $78 \%$ of the 100 accidents among the fishermen interviewed (Table 2). The fish that caused these types of injuries were: sorubins (Pseudoplatystoma sp), 24 cases; catfish (Pimelodus, Pimelodella and Rhamdia), 23 cases; jurupencens (Sorubim lima), 12 cases; jurupoca (Hemisorubim platyrhynchos), 3 cases; and stingrays (Potamotrygon sp),16 cases; as presented in Table 2.

Siluriformes, including sorubins (Pseudoplatystoma sp), jurupencens (Sorubim lima), jurupoca (Hemisorubim platyrhynchos) and catfish (Pimelodus, Rhamdia and Pimellodella) together totaled $62 \%$ of cases (Figure 1 and Table 2), causing a wide variety of symptoms and clinical complications (Table 3 ).

Despite representing only $16 \%$ of the 100 cases, the results observed in Tables $\mathbf{2}$ and $\mathbf{3}$ show that the majority of injuries from stingray barbs occurred in the feet of the victims and were associated with severe pain, paresthesia, lymphadenopathy, erythema, edema and skin necrosis, resulting in deep ulcers complicated by secondary bacterial infections (Figure 1) and extensive scarring. 
TABLE 3 - Relation of the fish associated with the lesions, the popular treatment used, symptoms, the duration of pain and layoff from work due to injuries and accidents.

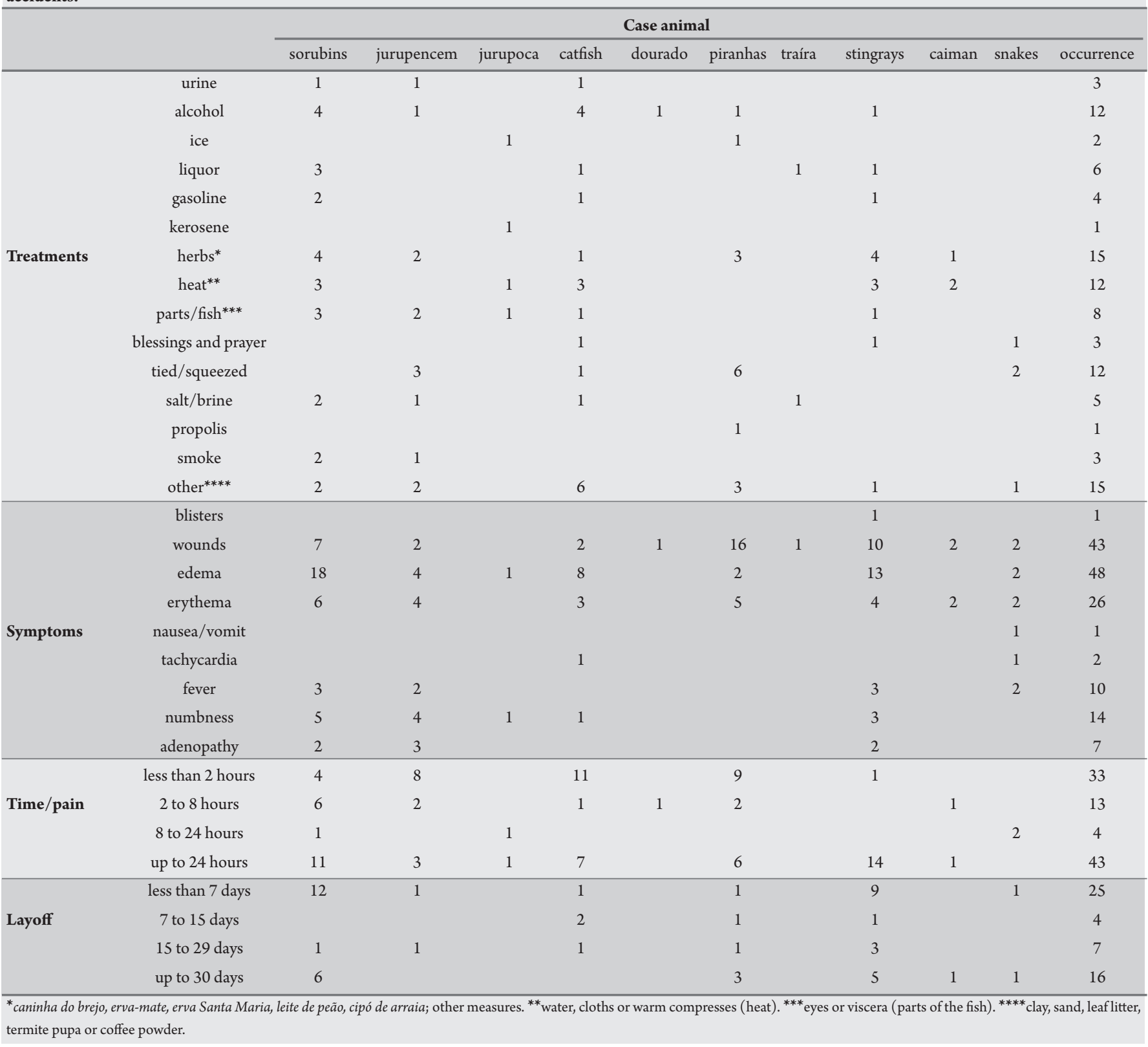

\section{DISCUSSION}

The capture of fish in natural conditions exposes the fisherman to a number of risks, since the preparation of fishing gear and coping with adverse natural conditions during the handling of fish, during or after fishing 5 .

The need to catch greater quantities of fish, in contradiction with the decline in productivity and price of fish, primarily due to over-fishing, the technological development of fishing tourism ${ }^{6}$ and negative environmental impacts caused to the Taquari River ${ }^{7}$ has led fishermen to exceed their physical limits regarding extensive working hours, exposing themselves to immediate hazards. This fact may also have contributed to making simple activities during the handling of fish (how to remove the fish hook, to enter in the water or handle the fish in the boat) the main causes of errors that resulted in accidents (Table 1). There are reports of similar problems in an investigation of injuries in rudimental fishermen of the Middle Araguaia River in State of Tocantins, Midwest region of Brasil ${ }^{8}$.

Some fishermen said that they remained on fishing trips in the Pantanal region for more than 60 days, often working day and night with short rest periods and facing adverse weather conditions. Only every two weeks, is the fish collected by support boats that go down the Taquari River with this objective and to carry supplies.

The reports made by two fishermen victims of necrotic ophidism, probably caused by boca-de-sapo snakes (Bothrops mattogrossensis) 9 , which is the most common species in Pantanal ${ }^{10}$, were associated with severe pain and hemorrhagic blisters, manifestations consistent with envenoming caused by this group of snakes.

Injuries caused by fish stings (Siluriformes and Rajiformes) are more frequent on the hands, but the present data show that a significant proportion of accidents ( $35 \%$ of cases) affected regions of the lower limbs (Table 1). When the sting penetrates the tissues of the victim, the barbs release toxins that flow into the wound causing violent pain 
and throbbing. The place becomes edematous and erythematous and the pain persists for more than six hours, with the possibility of infections that can last days (Table 3). This complication may indicate the presence of fragments of the stinger (Figure 1$)^{11}$. Bacterial infections are common factors complicating the accident and, in most cases are caused by Staphylococcus and Streptococcus, but may be associated with bacteria, such as Vibrio vulnificus (more common in marine environments) and Aeromonas hidrophyla, which cause severe infections with deep tissue necrosis (Figure 1) ${ }^{12}$.

In a previous report of 84 envenoming in humans caused by freshwater stingrays, the authors demonstrated that this is the most severe local injury caused by fish in Brazil, requiring controlled and professional treatment, often with opioid analgesics and antibiotics ${ }^{11}$.

Popular treatments reported by fishermen and used as palliative measures to ease the symptoms at the time of the accidents seem to be associated with moments of despair and lack of knowledge regarding the harmful effects of some substances used (Table 3). The use of gasoline and kerosene may aggravate the manifestations, increasing the pain and contributing to tissue necrosis.

Parts of the fish (eyes and viscera), organic and inorganic material in the soil (mud, leaves, sand), urine and pupae of termites were used in an attempt to alleviate the symptoms (Table 3), which in our view represents an increase risk due to the possibility of causing secondary infections.

All fishermen who used some thermal component on the affected sites for the treatment of injuries, by washing with hot water or placing a cloth or hot compresses or even urinating (12 cases) on the injury, said they experienced a significant reduction in pain, however momentary. Studies concerning the clinical and therapeutic aspects of accidents caused by mandijubas (the yellow catfish) report that main effect of the venom is intense vasoconstriction and the vasodilatation caused by hot water is responsible for the improvement in pain symptoms ${ }^{12,13}$. Immersing the affected area in hot water (around $50^{\circ} \mathrm{C}$ ) brings rapid relief to patients who must remain with injury immersed in hot water for 30-90 minutes.

More severe cases that required longer periods of removal may be related to lack of care and treatment or the lack of first aid measures by local health professionals, aggravated by the use of home treatment, carelessness in the treatment or the alleged delay in seeking medical attention.

In conclusion, accidents caused by aquatic animals in the regions where the fishermen were studied are very common; the animals mainly associated with the trauma are the most common fish and those of higher economic value; the severity of accidents is probably associated with inadequate and inefficient treatment; this study may be important for the fishing communities of the Pantanal region, since it provides information that assists in understanding the social, economic and environmental issues surrounding the proposed subject and there is a clear need to prepare printed material with guidance on the proposed subject that is adequately illustrated with the use of modern resources for graphic design and focused on language accessible to the fishermen.

\section{ACKNOWLEDGMENTS}

The authors would like to thank the Universidade AnhangueraUniderp and Universidade Estadual de Mato Grosso do Sul for providing support and contributing significantly to the pursuit of knowledge relevant to the achievement of the numerous stages of this research.

\section{CONFLICT OF INTEREST}

The authors declare that there is no conflict of interest.

\section{FINANCIAL SUPPORT}

Centro de Pesquisas do Pantanal (CPP). José Sabino is a fellow of CNPq (process 306169/2008-8).

\section{REFERENCES}

1. Resende EK. Recursos pesqueiros: diagnóstico e propostas de pesquisa. [Internet]. Corumbá: EMBRAPA-CPAP; 1988 [cited 2008 nov 21]. Avaliable from: http://www.cpap.embrapa.br/publicacoes.

2. Amâncio COG. Aspectos socioeconômicos do desenvolvimento do Pantanal Sul. In: Albuquerque ACS, Silva AG, editors. Agricultura Tropical: Quatro décadas de inovações tecnológicas, institucionais e políticas. $1^{\text {a }}$ edição. Corumbá (MS): Embrapa Pantanal; 2008. p. 503-517.

3. Haddad-Jr V. Infecções cutâneas e acidentes por animais traumatizantes em aquários comerciais e domésticos no Brasil: descrição de 18 casos e revisão do tema. An Br Dermatol 2004; 10:199-206.

4. Rotta MA. Situação da piscicultura Sul-mato-grossense e suas perspectivas no Pantanal. [Internet]. Corumbá: Embrapa Pantanal; 2003 Nov [cited 2008 nov 21]. Avaliable from: http://www.cpap.embrapa.br/publicacoes.

5. Dall'Oca AV. Aspectos socioeconômicos, de trabalho e de saúde de pescadores do Mato Grosso do Sul. [Dissertação de Mestrado]. [Campo Grande]: Universidade do Estado do Mato Grosso do Sul; 2004.

6. Catella AC, Albuquerque FF, Campos FLR. Sistema de Controle da Pesca de Mato Grosso do Sul SCPESCA/MS-6 - 1999. Boletim de Pesquisa e Desenvolvimento 35. EMBRAPA Pantanal; 2002.

7. Resende EK, Pereira RAC, Almeida VLL, Silva AG. Alimentação de peixes carnivoros da planície inundável do Rio Miranda, Pantanal, Mato Grosso do Sul, Brasil. [Internet]. Corumbá: EMBRAPA-CPAP; 1996 [cited 2008 nov 21]. Avaliable from: http://www.cpap.embrapa.br/publicacoes.

8. Garrone-Neto D, Cordeiro R, Haddad-Jr V. Acidentes do trabalho em pescadores artesanais da região do Médio Rio Araguaia, Tocantins, Brasil. Cad Saude Publica $2005 ; 21: 795-803$.

9. Cardoso JLC, França FOS, Wen FH, Malaque CMS, Haddad-Jr V. Animais Peçonhentos no Brasil: biologia, clínica e terapêutica. São Paulo: Editora Sarvier; 2009.

10. Monteiro C, Montgomery CE, Spina F, Sawaia RJ, Martins M. Feeding, Reproduction, and Morphology of Bothrops mattogrossensis (Serpentes, Viperidae, Crotalinae) in the Brazilian Pantanal. J Herpetol 2006; 40:408-413.

11. Haddad-Jr V, Garrone-Neto D, Paula-Neto JB, Marques FPL, Barbaro KC. Freshwater stingrays: study of epidemiologic, clinic and therapeutic aspects based in 84 envenomings in humans and some enzymatic activities of the venom. Toxicon 2004; 43:287-294.

12. Haddad Jr-V. Animais aquáticos potencialmente perigosos do Brasil: guia médico e biológico. São Paulo: Editora Roca; 2008.

13. Haddad Jr-V, Lastoria JC. Acidentes por mandijubas (mandis-amarelos): aspectos clínicos e terapêuticos. Diagnóstico e Tratamento 2005; 10:132-133. 